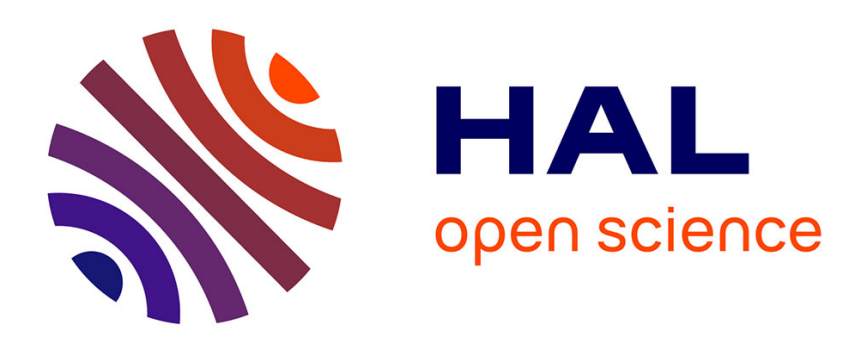

\title{
Combining ZDES with Immersed Boundary Conditions technique for the treatment of complex geometries
}

\author{
L. Mochel, P.E. Weiss, S. Deck
}

\section{To cite this version:}

L. Mochel, P.E. Weiss, S. Deck. Combining ZDES with Immersed Boundary Conditions technique for the treatment of complex geometries. 5th Symposium on Hybrid RANS/LES Methods, Mar 2014, HOUSTON, United States. hal-01079226

\section{HAL Id: hal-01079226 \\ https://hal.science/hal-01079226}

Submitted on 31 Oct 2014

HAL is a multi-disciplinary open access archive for the deposit and dissemination of scientific research documents, whether they are published or not. The documents may come from teaching and research institutions in France or abroad, or from public or private research centers.
L'archive ouverte pluridisciplinaire $\mathbf{H A L}$, est destinée au dépôt et à la diffusion de documents scientifiques de niveau recherche, publiés ou non, émanant des établissements d'enseignement et de recherche français ou étrangers, des laboratoires publics ou privés. 
Session:

\title{
Combining ZDES with Immersed Boundary Conditions technique for the treatment of complex geometries
}

\author{
L. Mochel , P.-É. Weiss and S. Deck \\ ONERA - The French Aerospace Lab, F-92190, Meudon, France
}

The present paper focuses on a numerical strategy called ZIBC consisting of the zonal use of the Immersed Boundary Conditions combined with the ability of Zonal Detached Eddy Simulation $[1,2]$ to simulate high Reynolds number separated flows. The motivation of such a strategy lies in the accurate handling of geometrically complex configurations with validated unsteady tools. Indeed, in the framework of scale-resolving unsteady simulations with a classical body-fitted mesh approach, the grid generation can become dramatically time-consuming or even unfeasible due to strict grid requirements. The aforementioned methodology appears to be a way to circumvent those limitations. In particular, it would be of considerable interest within the framework of space launcher afterbody by adding geometrical complexity to simplified configurations. Thus, we propose here to assess such a methodology on a simplified space launcher afterbody. The configuration consists of a cylinder elongated by another cylinder of smaller diameter (i.e. an extension). Immersed Boundary Conditions are used to handle the introduction of the extension into a pre-existing structured curvilinear grid fitting the ZDES grid requirements to treat the blunt body configuration (Fig. 1). The governing equations are solved using a standard body-fitted finite volume technique over the whole grid. A direct forcing source term, based on the work of [3] is used on the cells inside the emergence to drive the velocity and the turbulence variables to the chosen values. Numerical simulations are performed at a Reynolds number based on the larger diameter of $1.2 \times 10^{6}$ and a free stream Mach number of 0.702 . The numerical results are compared with the experimental (respectively numerical) data of [4-5] (respectively [6]), corresponding to the classical body-fitted mesh approach. Fig. 2 and Fig. 3 suggest that the emergence is properly taken into account. Furthermore, the pressure coefficient (see Fig. 4) illustrates a very good agreement between both the available experimental and ZDES numerical data (classical approach without IBC) and the current ZIBC simulation.

In the final version of the paper, the influence of the combination of Immersed Boundary Conditions technique with ZDES on the fluctuating pressure field around the immersed body will be evaluated within the framework of high Reynolds number separated flows. 
Session:

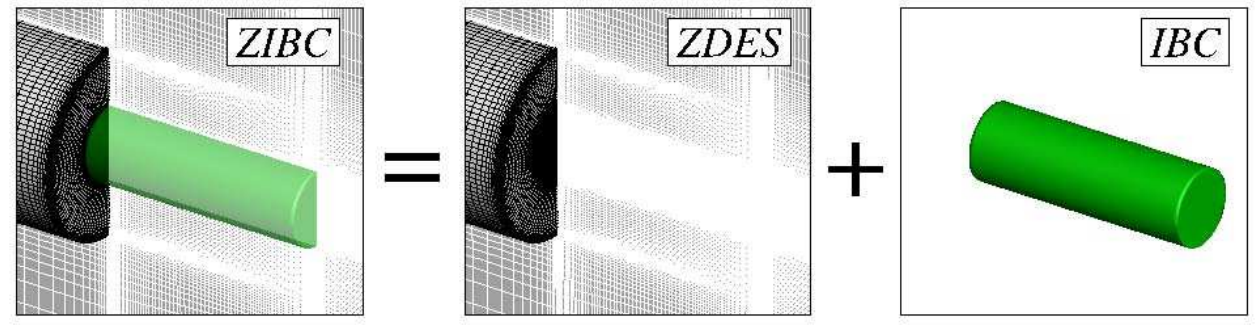

Fig. 1 Principle of ZIBC decomposed into classical primary approaches (i.e. ZDES and IBC)

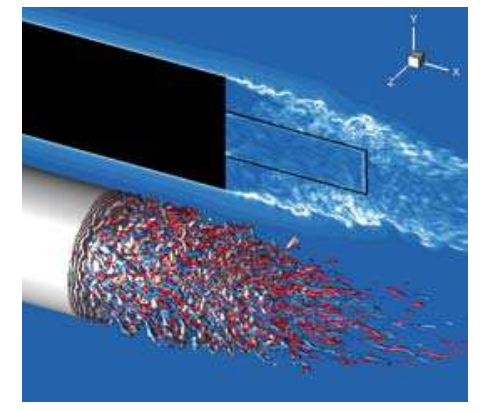

Fig. 2 Qualitative overview of the instantaneous flow field. Foreground: isosurface of Q criterion colored by the sign of streamwise vorticity (red for positive and blue for negative).

Background: iso-contours of the density gradient norm in the longitudinal plane

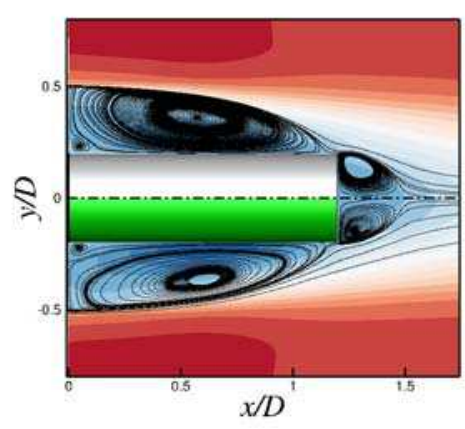

Fig. 3 Streamlines in the mean field with iso-contours of the streamwise velocity plotted on the longitudinal plane. Top: classical body-fitted approach. Bottom: present ZIBC

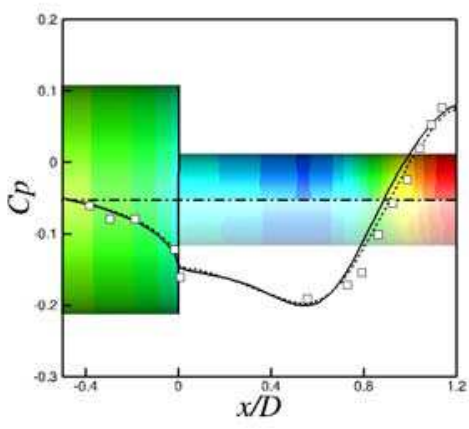

Fig. 4 Streamwise distribution of the mean pressure coefficient with the corresponding isocontours on the skin of the afterbody plotted in the background. Numerical simulations (ZDES): (-) classical approach, (- -) ZIBC. Experiments from [5]: (口)

\section{References}

[1] Deck, S., "Zonal-Detached-Eddy Simulation of the flow around a high-lift configuration", AIAA Journal, Vol. 43, 2005, pp. 2372-2384.

[2] Deck, S., "Recent improvements in the Zonal Detached Eddy Simulation (ZDES) formulation", Theoretical and Computational Fluid Dynamics, Vol. 26, No. 6, Dec. 2012, pp. 523-550.

[3] Mohd-Yusof, J., "Combined immersed-boundary/B-spline methods for simulations of flows in complex geometries", Annual Research Briefs, Center for Turbulence Research, 1997, pp. 317-328.

[4] Deprés, D. ,Reijasse, P., and Dussauge, J.-P., "Analysis of unsteadiness in afterbody transonic flows", AIAA Journal, Vol. 42, No. 12, 2004, pp. 2541-2550.

[5] Meliga, P., and Reijasse, P., "Unsteady transonic flow behind an axisymmetric afterbody equipped with two boosters" AIAA Paper 2007-4564, 25th AIAA Applied Aerodynamics Conference, Miami, FL, 2007, pp. 103-115.

[6] Weiss, P.-É., Deck, S., Robinet, J.-C., and Sagaut, P., "On the dynamics of axisymmetric turbulent separating/reattaching flows", Physics of Fluids, Vol. 21, No. 075103, 2009. 